\title{
Allegory of Dominance: British Power in Rudyard Kipling’s Rikki-tikki-tavi
}

\author{
Alexandre Veloso de Abreu \\ Pontifical Catholic University of Minas Gerais, Minas Gerais, Brazil
}

\begin{abstract}
In The Jungle Book (1894), Kipling's first literary work, the author uses Indian spatial reference and cultural influence to construct his narrative. The short story "Rikki-tikki-tavi” is elaborated using the structure of Western fables, having allegory as one of its most exploited strategies. Vladmir Propp, in Morphology of the Folktale (1929), considers that every folktale story reproduces a structure. Propp’s model demonstrates Rikki-tikki-tavi’s Western "frame” when the authors see how clearly and efficiently the short story fits the model of Russian Folktale. This article will analyze "Rikki-tikki-tavi” as a paradigm of this literary genre, showing how characters metaphorically represent the British domination in India during the end of the 19th century.
\end{abstract}

Keywords: Kipling, The Jungle Book, allegory, dominance

\section{Introduction}

Rudyard Kipling was born under the British Raj in Bombay, India, in 1865. As a child, he became fascinated by the Indian culture, specially literature and religion. Although Kipling spent his entire childhood in India, his upper education was in England, a common procedure done with the children of British officials in the Raj.

Advocating for Queen Victoria's expansionist kingdom, Kipling wrote a poem which illustrated his position concerning British Imperialism. “The White Man’s Burden” became a slogan, for Europeans often confronted the idea that capitalistic principles were the cause of imperialism, believing that European Imperialism was the natural way wealthier nations gained power. The nations unable to follow would be overwhelmed. In the poem, written to celebrate Queen Victoria's Diamond Jubilee, the poetic voice acts as a vaticinator, claiming that the glorious British Empire was at its end and that the United States of America would take over the burden of civilizing the world: “Take up the White Man’s burden/Ye dare not stoop to less” (Kipling, 1999, p. 253).

\section{Revisting a Writer of an Empire}

Although Kipling was contemplated with the Nobel Prize in 1907, George Orwell (1985) wrote an essay analyzing certain paradoxes of the writer's carrier. Orwell explains how aesthetically poor Kipling is, but at the same time, acknowledges his endurance in the British culture. As for Kipling's political position, he understands that the author of The Jungle Book is genuinely conservative:

Alexandre Veloso de Abreu, Ph.D., Department of Linguistics and Literature, Pontifical Catholic University of Minas Gerais. 
Although he had no direct connexion with any political party, Kipling was a Conservative, a thing that does not exist nowadays. Those who now call themselves Conservatives are either Liberals, Fascists or the accomplices of Fascists. He identified himself with the ruling power and not with the opposition. In a gifted writer this seems to us strange and even disgusting, but it did have the advantage of giving Kipling a certain grip on reality. The ruling power is always faced with the question, "In such and such circumstances, what would you DO?”, whereas the opposition is not obliged to take responsibility or make any real decisions. Where it is a permanent and pensioned opposition, as in England, the quality of its thought deteriorates accordingly. Moreover, anyone who starts out with a pessimistic, reactionary view of life tends to be justified by events, for Utopia never arrives and "the gods of the copybook headings", as Kipling himself put it, always return. Kipling sold out to the British governing class, not financially but emotionally. This warped his political judgement, for the British ruling class were not what he imagined, and it led him into abysses of folly and snobbery, but he gained a corresponding advantage from having at least tried to imagine what action and responsibility are like. It is a great thing in his favour. (Orwell, 1985, p. 83)

Kipling did believe in the good the Empire was doing to its colonies. "White man's burden" was a very popular notion until the end of the 19th century. It was understood that it was the responsibility of white Europeans to bring "proper" European civilization to the nations of other ethnical groups. The main motif was that Europeans were correct in their beliefs and it was their duty to bring everyone in the world up as close to the European standards as possible. During European and American Imperialism, “The white man’s burden” was often used as a justification for expansion and annexation. Europeans were responsible for educating "uncivilized” or "primitive” peoples. Kimball (2008) reminded us in his article Rudyard Kipling Unburdened that:

The key word is “civilization”. Kipling was above all the laureate not of Empire, but of civilization, especially civilization under siege. Henry James once sniffed that there was only one strain absent in Kipling: that of "the civilized man”. It's a frequent refrain. But in a deeper sense, Kipling was about almost nothing else—not the civilization of elegant drawing rooms, but something more primeval and without which those drawing rooms would soon be smashed and occupied by weeds. Kipling, Evelyn Waugh wrote toward the end of his life, "believed civilization to be something laboriously achieved which was only precariously defended. He wanted to see the defenses fully manned and he hated the liberals because he thought them gullible and feeble, believing in the easy perfectibility of man and ready to abandon the work of centuries for sentimental qualms”. Kipling endeavored to man those defenses partly through his political oratory, but more importantly through a literary corpus that taught the explicit lessons and the implicit rhythms of emotional continence and restraint. (p. 6)

While Edward Said (2000), speaking about the novel Kim (1901), sees the fictional work of Kipling as "a master work of imperialism" as well as "rich and absolutely fascinating, but nevertheless profoundly embarrassing...” (p. 9), Alicia Mistry understands that Rudyard Kipling felt the impact of the British Empire and the "Imperial Idea” more tangibly than any other Victorian novelist. Mistry clarifies that Kipling's Imperialism is not completely synonymous with British Imperialism, for Kipling experienced a personal involvement with India, a far-away and unfamiliar world for many of his contemporaries.

\section{The Jungle Book: A Fable}

In The Jungle Book (1894), Kipling’s first literary work, the author uses Indian spatial reference and cultural influence to construct his narrative. The short story "Rikki-tikki-tavi” is elaborated using the structure of Western fables, having allegory as one of its most exploited strategies. The author can observe that "Rikki-tikki-tavi” can be seen as a paradigm of this literary genre, showing how characters metaphorically represent the British domination in India during the end of the 19th century.

Kipling uses a very common resource in fables known as anthropomorphism (when animals are characterized 
with human traits). This is, in fact, the trait that mostly defines the genre fable, for all main characters are animals. The term fable is said to derive from the Latin radical fari, meaning "to speak", or a variation of phao, from Greek, meaning "to tell something”. The narrative has a symbolic nature where the animals live a "human situation" with the objective of transmitting a moral or of giving an example of conduct, generally one belonging to a dominant ideology of the period in which the story was told. Most of the time the moral is unquestionable and the maintenance of the status quo seems to be the main issue. Generally, the values of a dominant social class are transmitted through the themes of the majority of the narratives. Fables offer a model of Manichaeism, where "good" must be reproduced and "evil" rejected. The strong presence of animals is due to the fact that human society had intense interaction and depended immensely on animal force in the past. This approached people to the story and the associations with human situations were easily assimilated. Through efabulation we receive the moral of the fable, commonly reduced to an epithimio, a type of aphorism, containing the lesson.

It can be noticed in Kipling's narrative that this rich literary genre is exploited. The writer introduces the story with a poem presenting the main character almost as in an epic invocation. A summary of events that will be given details in the narrative instigates the reader to continue. A clue of Manichaeism can be detected, when the introduction elects the mongoose as the good hero:

This is the story of the great war that Rikki-tikki-tavi fought single-handed, through the bath-rooms of the big bungalow in Segowlee cantonment. Darzee, the tailor-bird, helped him, and Chuchundra, the musk-rat, who never comes out into the middle of the floor, but always creeps round by the wall, gave him advice; but Rikki-tikki did the real fighting. He was a mongoose, rather like a little cat in his fur and his tail, but quite like a weasel in his head and his habits. His eyes and the end of his restless nose were pink; he could scratch himself anywhere he pleased, with any leg, front or back, that he chose to use; he could fluff up his tail till it looked like a bottle-brush, and his war-cry, as he scuttled through the long grass, was: “Rikk-tikk-tikki-tikki-tchk!”. (Kipling, 2000b, p. 30)

Notice that there is a detailed description of the physical traits of the mongoose, and the references are animals that would be recognized by Western readers. The exotic mongoose is immediately paralleled with animals of the European continent, already showing a need to translate the exotic to a "civilized" reference.

From now on animals are going to feature as the main characters, each one containing Kipling's notion of good and evil. Allegorically, the animals chosen can be seen as representations of the British colonial influence in India, some standing for the natives that resisted and the others as natives that assimilated Western ideals.

Table 1 shows the allegorical associations of the main characters in Rikki-tikki-tavi:

Vladmir Propp, in Morphology of the Folktale (1929), considers that every folktale story reproduces a structure that can be defined as the following: Mark zero, the initial harmony is presented. First, every efabulation has a nuclear motivation, an aspiration or purpose, caused by a lack of some type that leads the hero or heroine to an action; Second, the condition to execute this purpose is to leave home, go on a quest. The hero travels or dislocates to a non-familiar place; Third, there are challenges and many obstacles that must be surpassed by the hero or heroine; And fourth, a mediator appears, of natural or supernatural origin, to help the hero or heroine with the obstacles; Fifth and last element, the hero conquers his objective and receives his reward. All these invariants have innumerous variants and many secondary challenges could show up. Table 2 exemplifies these structural elements in Rikki-tikki-tavi: 
Table 1

Characters and Their Allegorical Descriptions

\begin{tabular}{|c|c|c|}
\hline Character & & Allegorical description \\
\hline Rikki-tikki-tavi & & $\begin{array}{l}\text { The main character of the short story, the mongoose was chosen to represent the cordiality } \\
\text { of the colonized. Gratitude is shown, for the English boy helps the mongoose. The } \\
\text { retribution is the protection from the snakes. }\end{array}$ \\
\hline Nag \& Nagaina & & $\begin{array}{l}\text { The King Cobras are the antagonists of the story. Symbols of resistance of the colonization } \\
\text { process, they carry the inscription of the Hindu god Brahm in their hood, god considered } \\
\text { pagan in European cultures. Different from Western societies, snakes do not have an evil } \\
\text { representation in Eastern ones. In India, for instance, they represent cunning, strength and } \\
\text { stealth. Indian mythology recognizes nagas as mediators between gods and humans. They } \\
\text { are generally associated with the rainbow. The Kundalini serpent is shown intertwined with } \\
\text { the spinal cord and is known to be the symbol of life and cosmic energy. The nagas, } \\
\text { representing evil in the Manichaeistic model of the story, show the strong Western canonic } \\
\text { traits in Kipling's fiction, contributing to the allegory of colonial resistance. The female } \\
\text { Nagaina has a more intense contact with the land. In myths, it is common to associate the } \\
\text { female figure with the earth and it would be coherent to say that Nagaina would symbolize } \\
\text { the identity of pre-colonized India and the secular culture that will maintain its traits even } \\
\text { after the great influence of the British Raj. }\end{array}$ \\
\hline Darzee & & $\begin{array}{l}\text { The Tailorbird interacts with Rikki-tikki-tavi in a very significant way. He alerts the } \\
\text { mongoose of Nagaina's attack, showing that it agrees with the cobras being the disharmony } \\
\text { of the yard, the menace that must be dealt with. Interesting to notice that the female } \\
\text { tailorbird is a more efficient guide. When couples appear in the story, the female has a more } \\
\text { complex elaboration, as can be noticed with Nagaina, the king cobra. }\end{array}$ \\
\hline Chuchundra & & $\begin{array}{l}\text { Chuchundra, the muskrat, is afraid of Rikki-tikki-tavi which, in a whole, describes his } \\
\text { fragile state. It is in constant fear of Nag and Nagaina. The muskrat allegorizes the } \\
\text { situations of most of the colonized, showing fear of the colonizer and at the same time fear } \\
\text { of making a stand. He never shows himself, crawling close to the walls. Rikki-tikki-tavi } \\
\text { mediates, convincing the creature the yard is safer for it belongs to Teddy and family. }\end{array}$ \\
\hline Teddy & & $\begin{array}{l}\text { British families lived in open, airy houses called bungalows to protect them from the hot } \\
\text { sun. Because of the rain, bushes could grow considerably. It was not unusual for snakes and } \\
\text { other animals to find their way into a house. This act is an allegorical representation of how } \\
\text { the colonizer interacted with the colonized but maintained their distance nonetheless. } \\
\text { Teddy is protected by the cordiality of Rikki-tikki-tavi, the mongoose seems to understand } \\
\text { and assimilate the Imperialistic domination and guards the foreigners from the other fauna, } \\
\text { viz, natives of the forest. }\end{array}$ \\
\hline
\end{tabular}

Table 2

Summerized Proppian Model of Narrative

\begin{tabular}{|l|l|}
\hline Invariant elements & Variant elements \\
\hline Initial harmony & Rikki-tikki is at the forest before the flood. \\
\hline Lack & The mongoose receives instructions from his mother. \\
\hline Quest & The flood drags Rikki-tikki to the garden. \\
\hline Magical helpers/opponents & Rikki-tikki is presented to the other animals and his enemies: Nag and Nagaina. \\
\hline Test & The mongoose endures the harness of the battles with the cobras. \\
\hline Rewards & Rikki-tikki frees the garden from the snakes. \\
\hline
\end{tabular}

Propp’s model demonstrates Rikki-tikki-tavi’s Western “frame” when we see how clearly and efficiently the short story fits the model of Russian Folktale. Again, a picture of how white Kipling's India is.

\section{Conclusions}

Although an emblem of Imperialism, Rudyard Kipling is acknowledged for is outstanding work as a writer and for his elaborate use of narrative elements. It is to be seen if such content is subdued by his naïveté 
concerning the practice of domination. Until then we continue to witness “The White Man’s Burden” taking place, not always soothed by high quality literature.

\section{References}

Kimball, R. (2008). Rudyard kipling unburdened. New York: The New Yorker.

Kipling, R. (1990). Something of myself, and other autobiographical writings. In T. Pinney (Ed.), Cambridge: Cambridge University Press.

Kipling, R. (1999). Collected poems of Rudyard Kipling. London: Wordsworth Editions Ltd..

Kipling, R. (2000a). Kim. New York: Penguin Classics.

Kipling, R. ( 2000b). The jungle book. New York: Penguin Classics.

Orwell, G. ( 1985). Fifty essays. New York: Benediction Classics.

Propp, V. (1968). Morphology of the folktale (2nd ed.). (L. Scott Trans.). Austin: University of Texas Press.

Said, E. (1989). Representing the colonized: Anthropology’s interlocutors. Critical Inquir, 15, 205-225.

Said, E. (1994a). Culture and imperialism. New York: Vintage Books.

Said, E. (1994b). Secular interpretation, the geographical element, and the methodology of imperialism. In G. Prakash (Ed.), After colonialism: Imperial histories and postcolonial displacements. Princeton: Princeton University Press.

Said, E. (2000). Introduction. In R. Kipling (Ed.), Kim. New York: Penguin Classics.

Spivak, G. C. (1999). A critique of postcolonial reason: Toward a history of the vanishing present. Cambridge: Harvard University Press. 